\title{
Hepatocellular Carcinoma cM1 TNM Finding v8
}

National Cancer Institute

\section{Source}

National Cancer Institute. Hepatocellular Carcinoma CM1 TNM Finding v8. NCI

Thesaurus. Code C134462.

Hepatocellular carcinoma with distant metastasis. (from AJCC 8th Ed.) 